Supporting Information

\title{
Heterogeneous Structure Regulated by Selection Pressure on Bacterial Adhesion Optimized the Viability Stratification Structure of Electroactive Biofilms
}

Xuepeng Chen ${ }^{a}$, Yunfei Li ${ }^{a}$, Jingxuan $W^{a}{ }^{a}$, Nan Li ${ }^{a}$, Weihua He ${ }^{a}$, Yujie Feng ${ }^{a, b}$, Jia Liu $^{a *}$

aSchool of Environmental Science and Engineering, Academy of Environment and Ecology,

Tianjin University, No. 92 Weijin Road, Nankai District, Tianjin, 300072, China

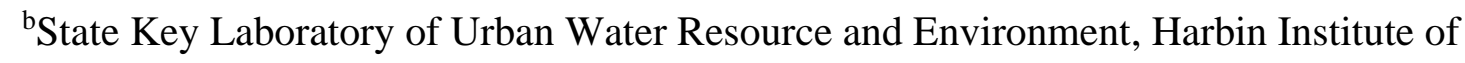

Technology, No. 73 Huanghe Road, Nangang District, Harbin, 150090, China

*Corresponding Author:

E-mail: jialiu1@tju.edu.cn 
Part S1 Physicochemical Properties of Anode Materials

(a)
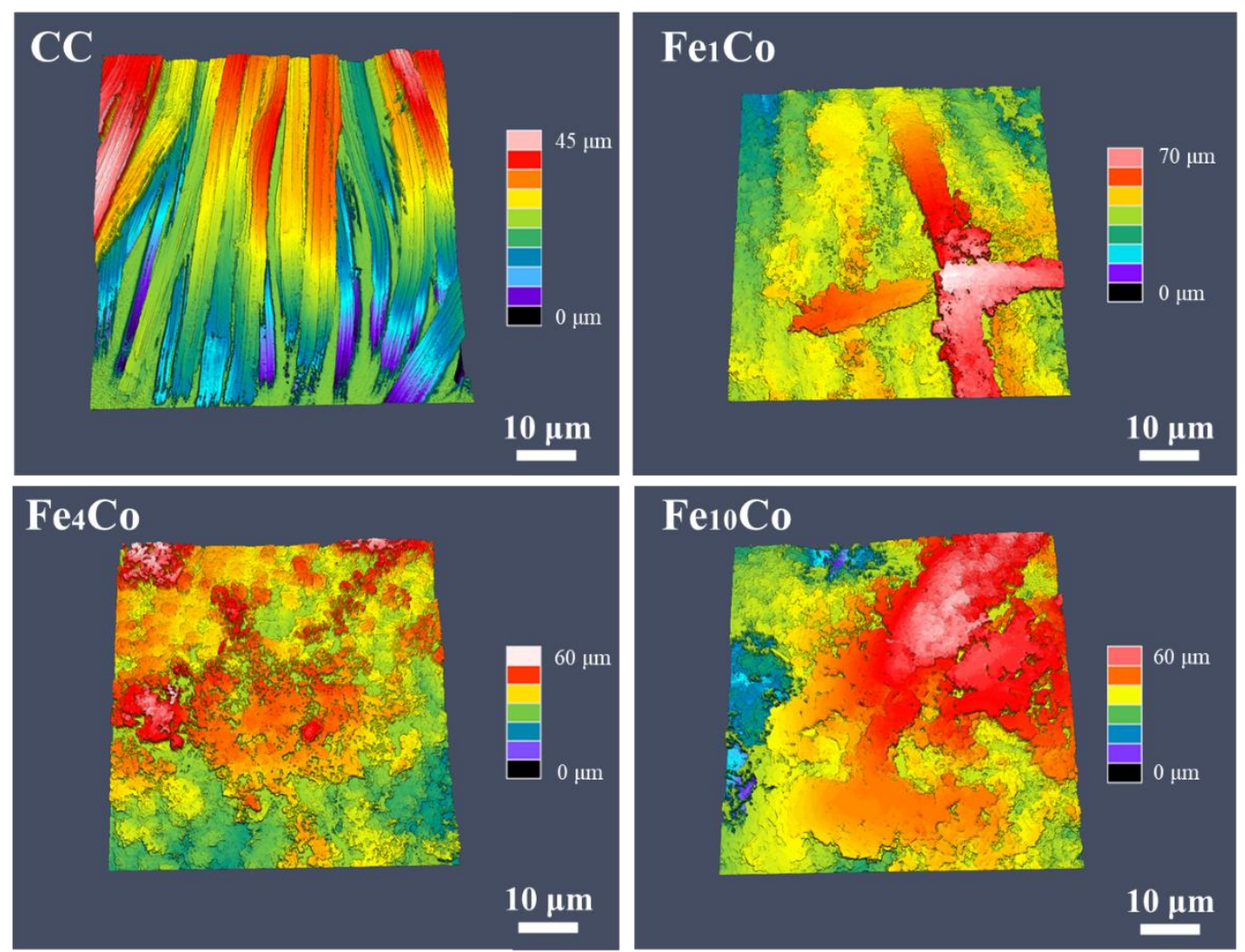

(b)
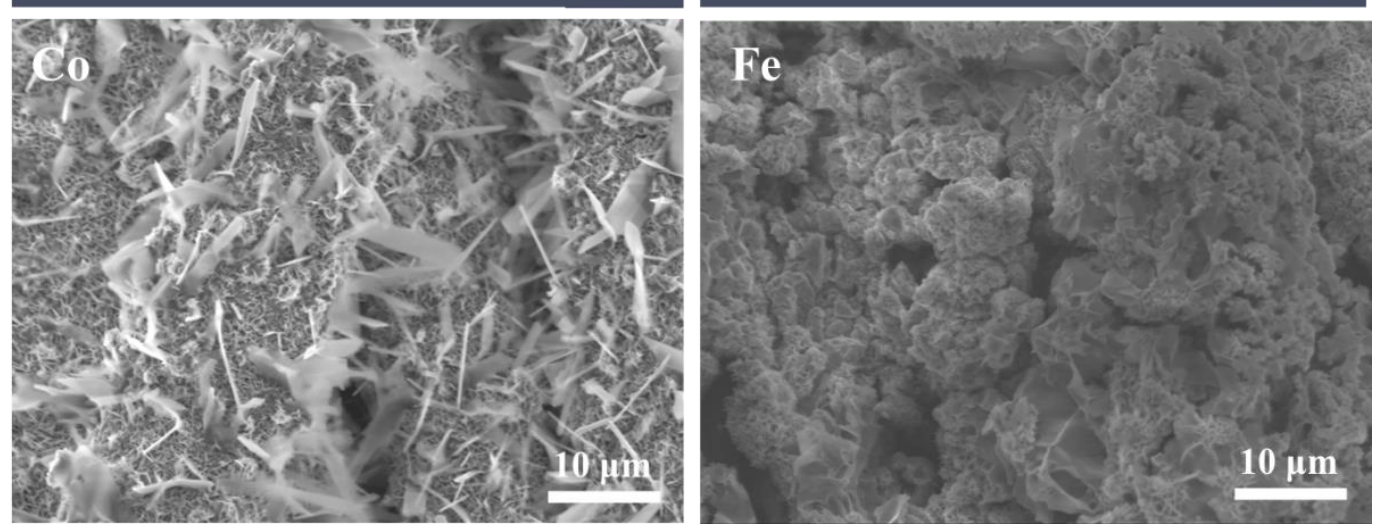

Figure S1. (a) CLSM images of the $\mathrm{CC}, \mathrm{Fe}_{1} \mathrm{Co}, \mathrm{Fe}_{4} \mathrm{Co}$, and $\mathrm{Fe}_{10} \mathrm{Co}$ electrodes. (b) SEM images of the Co and Fe electrodes. 


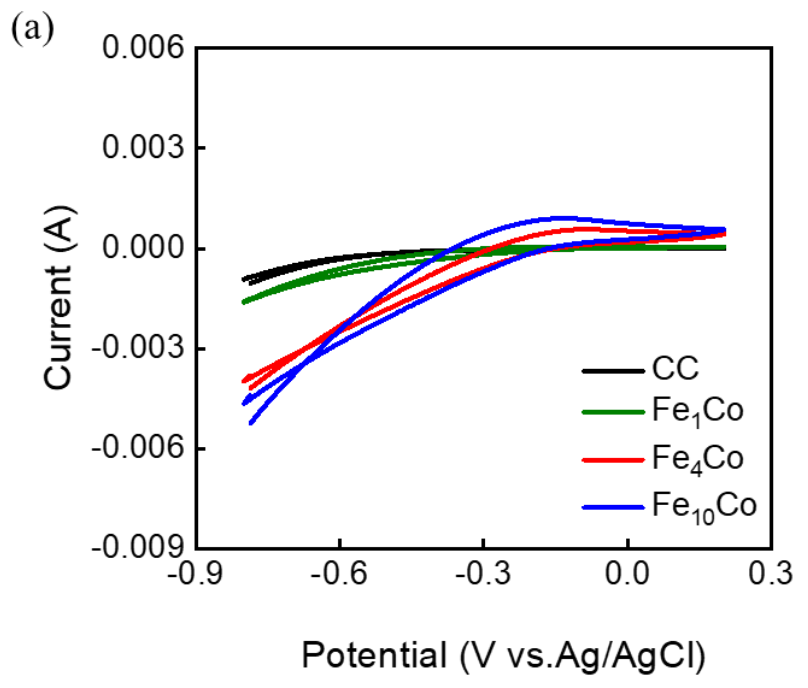

(b)

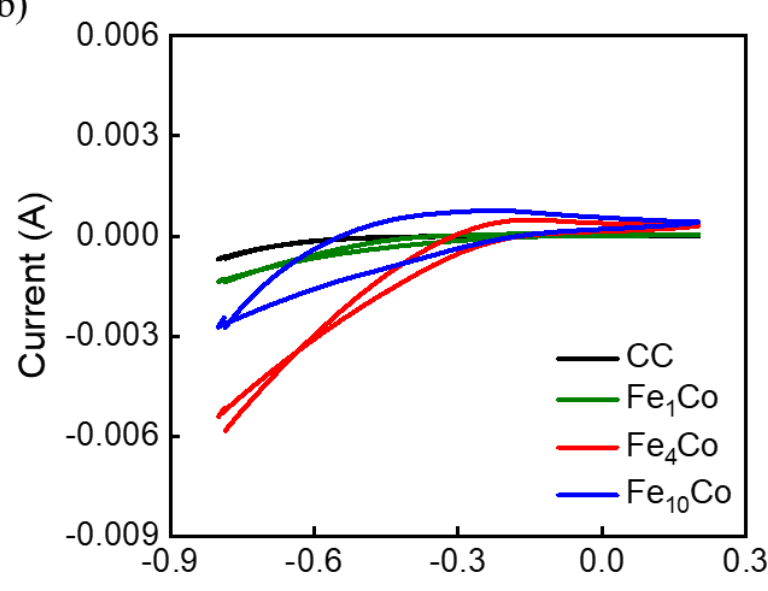

Potential (V vs.Ag/AgCl)

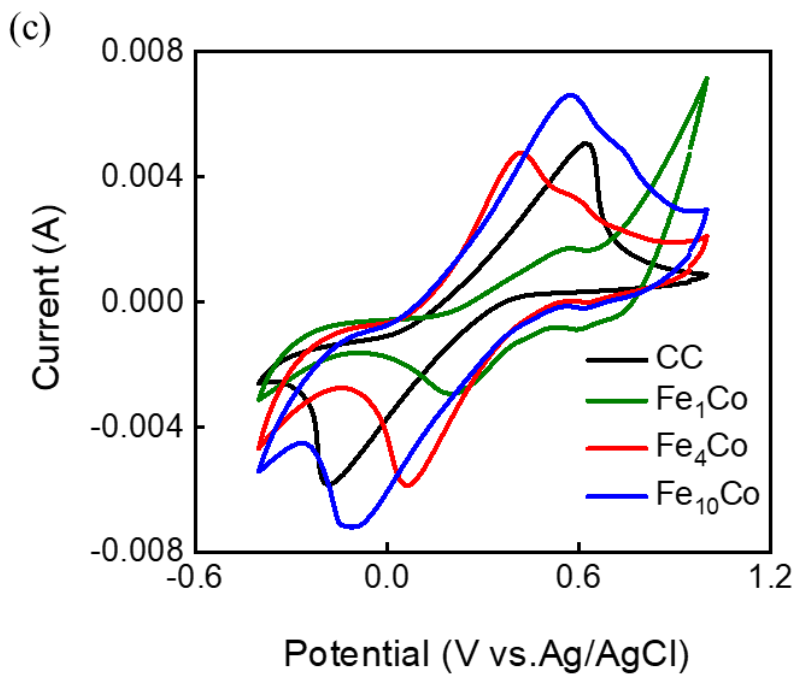

Figure S2. The CV curves of electrodes before inoculation in different anolytes: (a) culture medium solution without acetate; (b) culture medium solution containing acetate; (c) $10 \mathrm{mM}$ $\mathrm{K}_{3}\left[\mathrm{Fe}(\mathrm{CN})_{6}\right]$ containing $0.2 \mathrm{M} \mathrm{Na}_{2} \mathrm{SO}_{4}$. 
Electrochemical active surface area (ECSA) reflects the area with conductive path to transfer electrons on the electrode surface. ${ }^{1}$ The ECSA related to the electrocatalytic activity of different electrodes were displayed in Figure S2c. All the electrodes showed a pair of obvious redox peaks and ECSA values for $\mathrm{CC}, \mathrm{Fe}_{1} \mathrm{Co}, \mathrm{Fe}_{4} \mathrm{Co}$, and $\mathrm{Fe}_{10} \mathrm{Co}$ were $7.9 \mathrm{~cm}^{2}, 2.7$ $\mathrm{cm}^{2}, 7.4 \mathrm{~cm}^{2} \mathrm{~cm}^{2}$, and $10.3 \mathrm{~cm}^{2}$, respectively. Large ECSA is beneficial for electrons capture to improve the anodic electrocatalytic activity and power output of MFCs. As demonstrated in the text, however, $\mathrm{Fe}_{4} \mathrm{Co}$ had a slightly lower ECSA compared with the $\mathrm{CC}$ and $\mathrm{Fe}_{10} \mathrm{Co}$ but provided the largest catalytic current and power density, suggesting that $\mathrm{EAB}$ on the $\mathrm{Fe}_{4} \mathrm{Co}$ played an important role in the energy output process. 
Part S2 Characterizations of electroactive biofilms

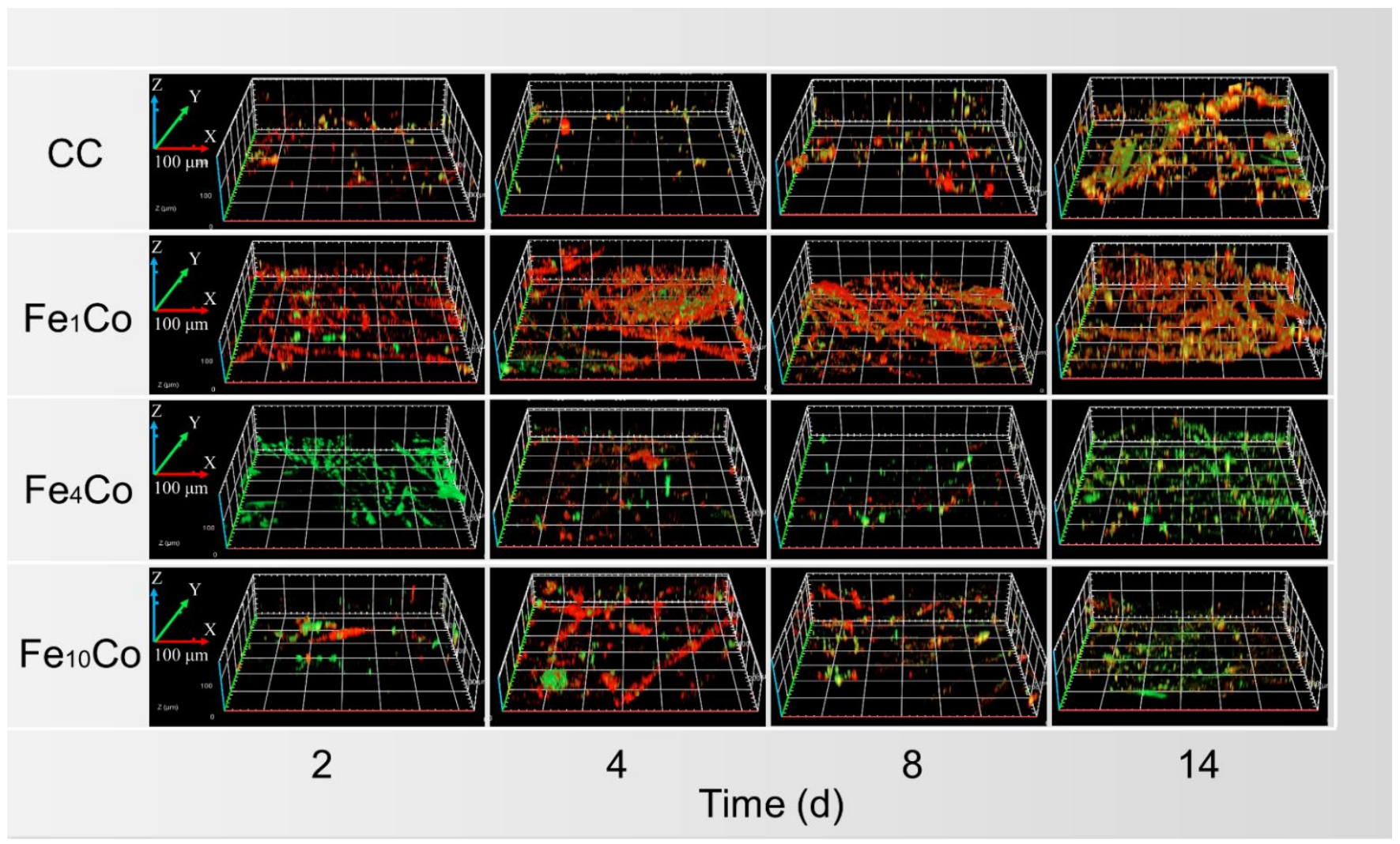

Figure S3. CLSM images of biofilms on different electrodes at the end of days 2, 4, 8, and

14. Cells with low viability and damaged membranes stained red, while cells with high viability and intact membranes stained green. 


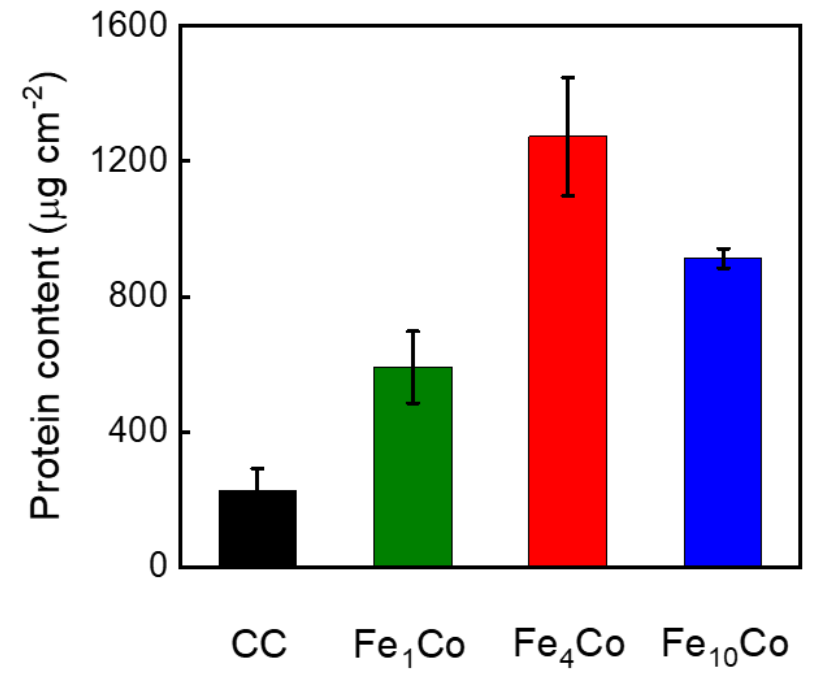

Figure S4. The biomass of $\mathrm{CC}, \mathrm{Fe}_{1} \mathrm{Co}, \mathrm{Fe}_{4} \mathrm{Co}$, and $\mathrm{Fe}_{10} \mathrm{Co}$ bioanodes (error bars were based on averages measured in triplicate). 

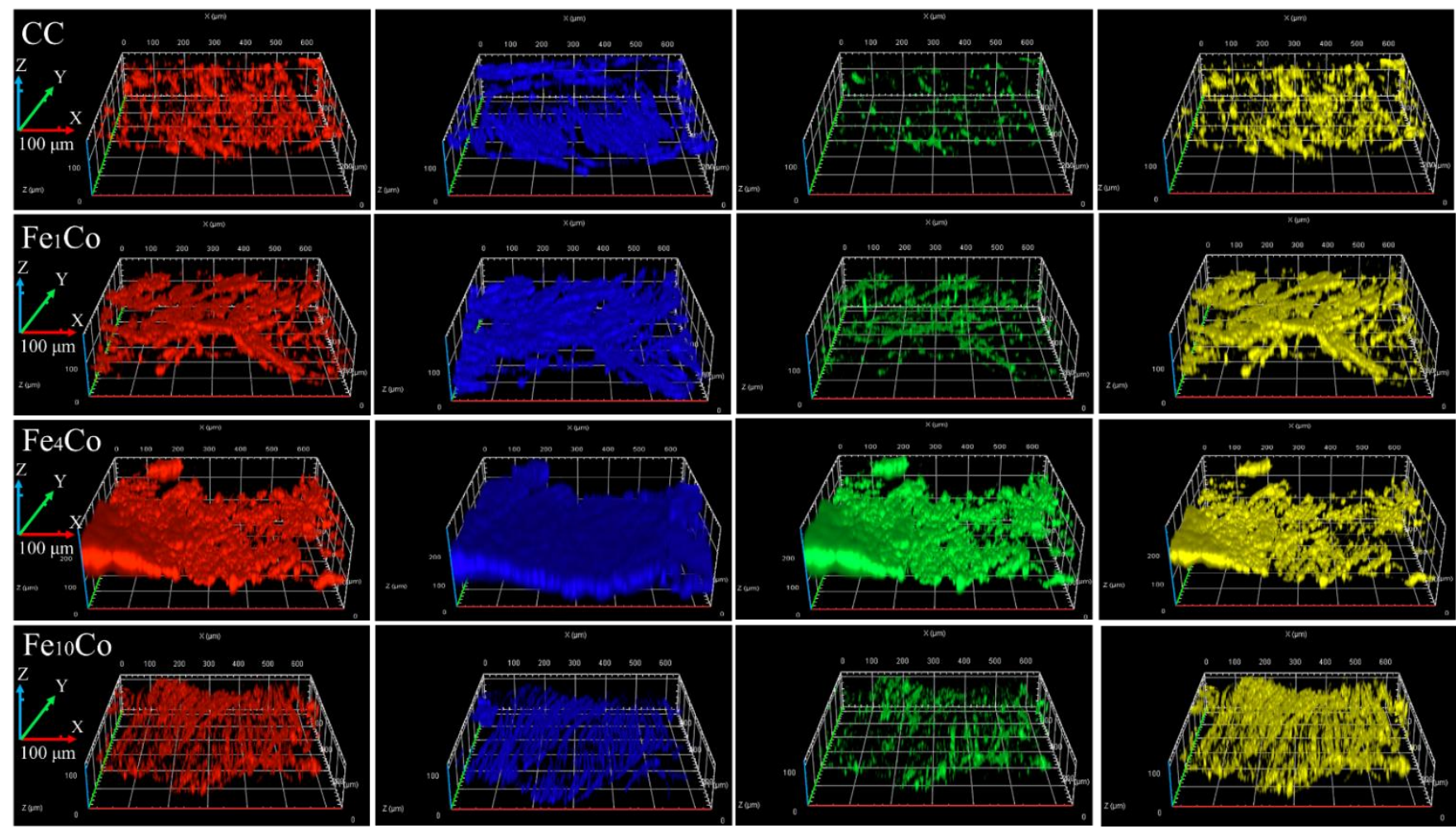

Figure S5. EPS distribution of biofilms attached on the $\mathrm{CC}, \mathrm{Fe}_{1} \mathrm{Co}, \mathrm{Fe}_{4} \mathrm{Co}$, and $\mathrm{Fe}_{10} \mathrm{Co}$

electrodes. Biofilms were simultaneously stained with FITC (proteins in green), Con A ( $\alpha$-Dglucopyranose polysaccharides in red), CW ( $\beta$-D-glucopyranose polysaccharides in blue) and Nile Red (Lipids in yellow). 
(a)

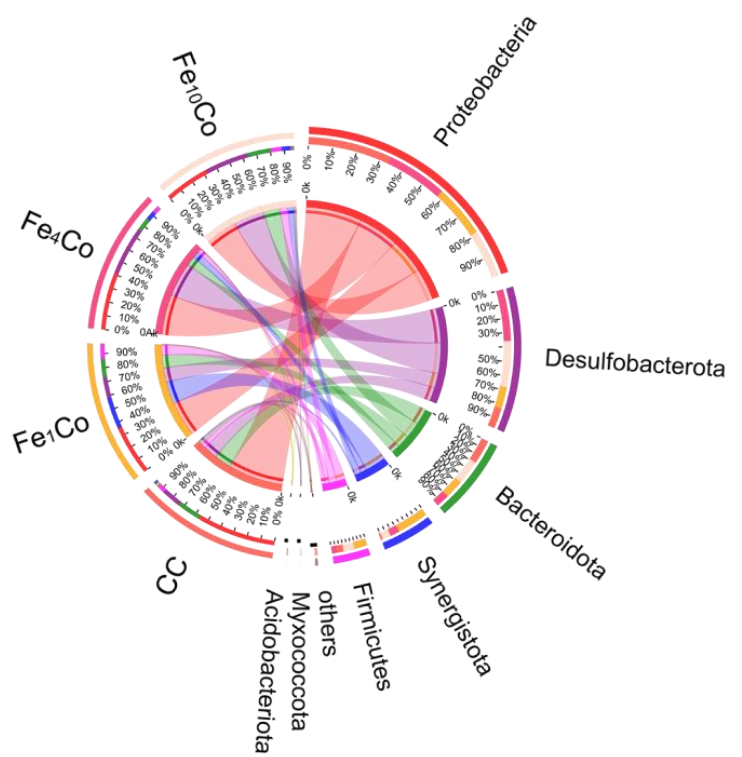

(b)
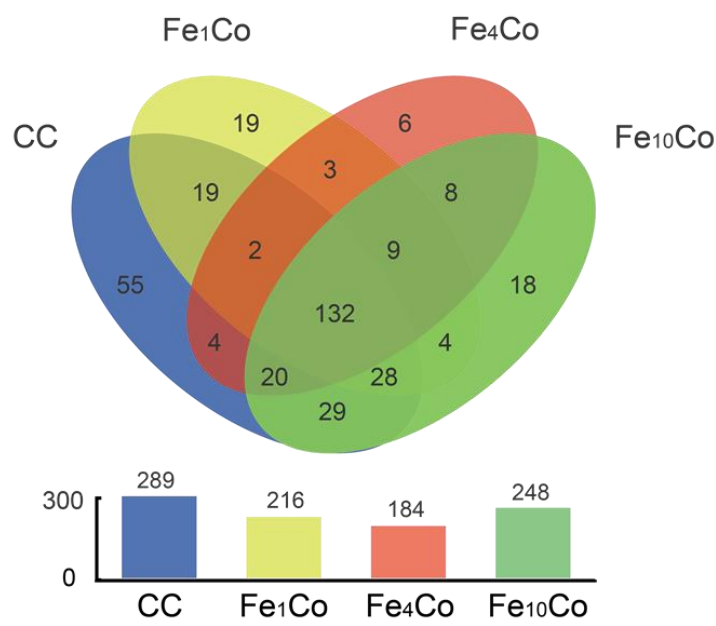

Figure S6. (a) Microbial community compositions of different anode biofilms at the phylum level. (b) Venn diagram of different anode biofilms at the genus level. 


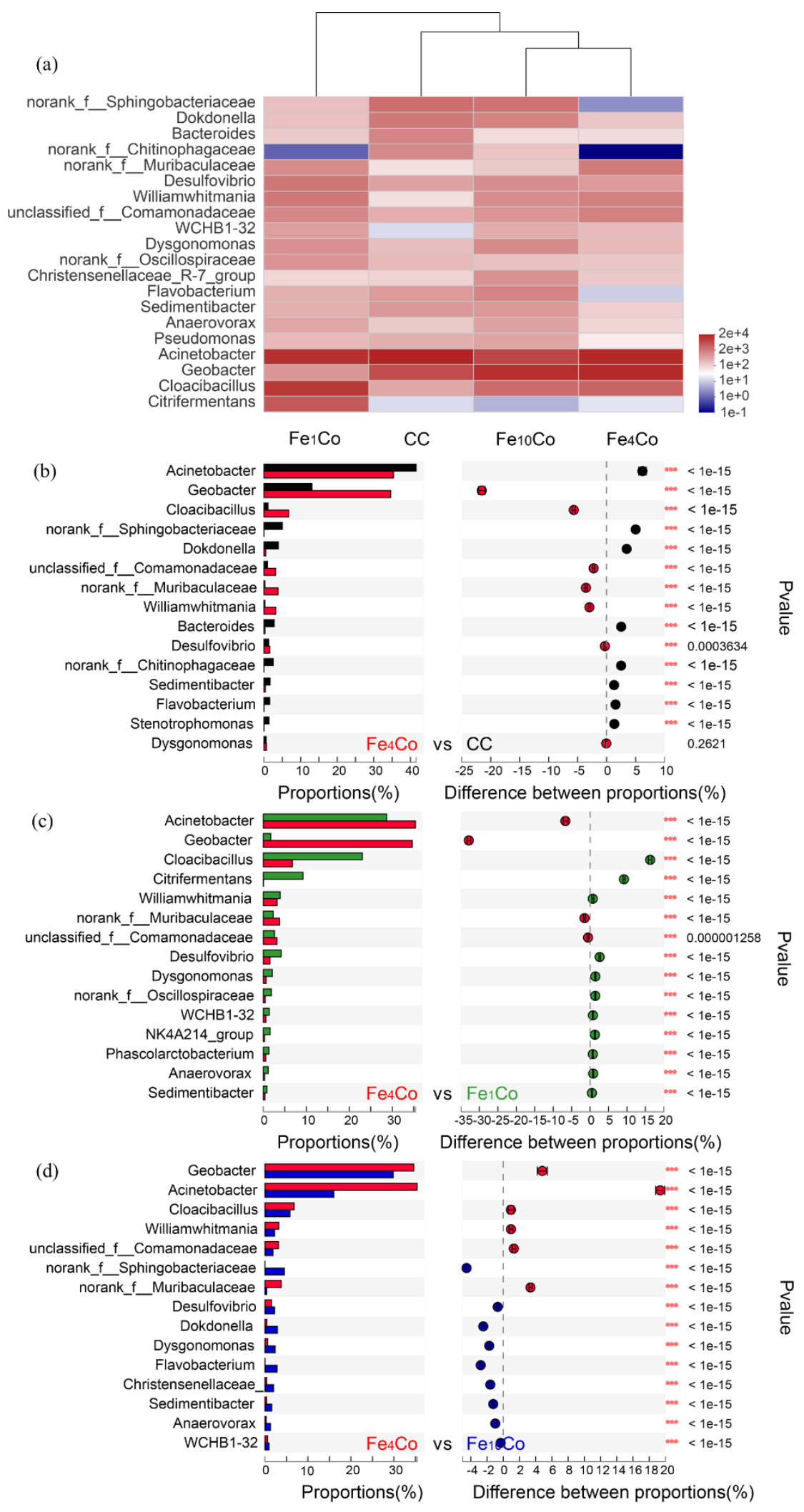

Figure S7. (a) Heatmap and cluster analysis of different anode biofilms at the genus level.

The sequence abundance (95\% confidence intervals) of main genera: (b) $\mathrm{Fe}_{4} \mathrm{Co}$ and $\mathrm{CC}$, (c)

$\mathrm{Fe}_{4} \mathrm{Co}$ and $\mathrm{Fe}_{1} \mathrm{Co}$, and (d) $\mathrm{Fe}_{4} \mathrm{Co}$ and $\mathrm{Fe}_{10} \mathrm{Co}$. 


\section{Part S3 Tables}

Table S1. Compositions of electrolytes for preparation of hybrid electrodes.

\begin{tabular}{ccc}
\hline & \multicolumn{2}{c}{ Electrolytes } \\
\cline { 2 - 3 } $\mathrm{Fe}_{x} \mathrm{Co}$ electrode & $\mathrm{c}(\mathrm{Fe}(\mathrm{II}))+\mathrm{c}(\mathrm{Co}(\mathrm{II}))$ & $\mathrm{c}(\mathrm{Fe}(\mathrm{II})): \mathrm{c}(\mathrm{Co}(\mathrm{II}))$ \\
\hline $\mathrm{Fe}_{1} \mathrm{Co}$ & $0.1 \mathrm{M}$ & $4: 1$ \\
$\mathrm{Fe}_{4} \mathrm{Co}$ & $0.1 \mathrm{M}$ & $10: 1$ \\
$\mathrm{Fe}_{10} \mathrm{Co}$ & $0.1 \mathrm{M}$ & \\
\hline
\end{tabular}


Table S2. Concentrations of vitamins in solution added to inoculum.

\begin{tabular}{cc}
\hline Composition & $\mathrm{mg} \mathrm{L}^{-1}$ \\
\hline Folic acid & 2 \\
Pyridoxine HCl & 10 \\
Riboflavin & 5 \\
Thiamin & 5 \\
Nicotinic acid & 5 \\
Pantothenic acid & 5 \\
B-12 & 0.1 \\
P-aminobenzoic acid & 5 \\
Thioctic acid & 5 \\
\hline
\end{tabular}


Table S3. Concentrations of minerals in solution added to inoculum.

\begin{tabular}{|c|c|}
\hline Composition & $\mathrm{mg} \mathrm{L}^{-1}$ \\
\hline NTA & 2 \\
\hline $\mathrm{MgSO}_{4}$ & 3 \\
\hline $\mathrm{MnSO}_{4} \cdot \mathrm{H}_{2} \mathrm{O}$ & 0.5 \\
\hline $\mathrm{NaCl}$ & 1 \\
\hline $\mathrm{FeSO}_{4} \cdot 7 \mathrm{H}_{2} \mathrm{O}$ & 0.1 \\
\hline $\mathrm{CaCl}_{2} \cdot 2 \mathrm{H}_{2} \mathrm{O}$ & 0.1 \\
\hline $\mathrm{CoCl}_{2} \cdot 6 \mathrm{H}_{2} \mathrm{O}$ & 0.1 \\
\hline $\mathrm{ZnCl}_{2}$ & 0.13 \\
\hline $\mathrm{CuSO}_{4} \cdot 5 \mathrm{H}_{2} \mathrm{O}$ & 0.01 \\
\hline $\mathrm{AlK}\left(\mathrm{SO}_{4}\right)_{2} \cdot 12 \mathrm{H}_{2} \mathrm{O}$ & 0.01 \\
\hline $\mathrm{H}_{3} \mathrm{BO}_{3}$ & 0.01 \\
\hline $\mathrm{Na}_{2} \mathrm{MoO}_{4}$ & 0.025 \\
\hline $\mathrm{NiCl}_{2} \cdot 6 \mathrm{H}_{2} \mathrm{O}$ & 0.024 \\
\hline $\mathrm{Na}_{2} \mathrm{WO}_{4} \cdot 2 \mathrm{H}_{2} \mathrm{O}$ & 0.025 \\
\hline
\end{tabular}


Table S4. Elemental compositions of different electrodes from XPS analysis.

\begin{tabular}{cccccc}
\hline Samples & $\mathrm{C}(\mathrm{At} \%)$ & $\mathrm{O}(\mathrm{At} \%)$ & $\mathrm{S}(\mathrm{At} \%)$ & $\mathrm{Fe}(\mathrm{At} \%)$ & $\mathrm{Co}(\mathrm{At} \%)$ \\
\hline $\mathrm{Fe}_{1} \mathrm{Co}$ & 59.45 & 27.90 & 2.82 & 7.44 & 2.39 \\
$\mathrm{Fe}_{4} \mathrm{Co}$ & 48.47 & 36.38 & 1.84 & 10.62 & 2.69 \\
$\mathrm{Fe}_{10} \mathrm{Co}$ & 28.93 & 47.22 & 3.50 & 17.74 & 2.61 \\
\hline
\end{tabular}


Table S5. Summary of the alpha diversities of bacterial communities in the different electrode biofilms.

\begin{tabular}{ccccccc}
\hline Samples & OTU num & ACE & Shannon index & Simpson & Chao 1 & Coverage \\
\hline $\mathrm{CC}$ & 431 & 480.00 & 3.69 & 0.06 & 470.72 & 1.00 \\
$\mathrm{Fe}_{1} \mathrm{Co}$ & 349 & 362.92 & 3.35 & 0.08 & 353.81 & 1.00 \\
$\mathrm{Fe}_{4} \mathrm{Co}$ & 287 & 362.80 & 2.32 & 0.22 & 357.00 & 1.00 \\
$\mathrm{Fe}_{10} \mathrm{Co}$ & 381 & 480.96 & 3.37 & 0.11 & 497.63 & 1.00 \\
\hline
\end{tabular}


Table S6. The relative abundance of known exoelectrogens in different anodic biofilms.

\begin{tabular}{ccccc}
\hline \multirow{2}{*}{ Genus } & \multicolumn{5}{c}{ Relative Abundance (\%) } \\
\cline { 2 - 5 } & $\mathrm{CC}$ & $\mathrm{Fe}_{1} \mathrm{Co}$ & $\mathrm{Fe}_{4} \mathrm{Co}$ & $\mathrm{Fe}_{10} \mathrm{Co}$ \\
\hline Acinetobacter & 42.00 & 29.00 & 35.00 & 16.00 \\
Geobacter & 13.00 & 1.80 & 35.00 & 30.00 \\
Desulfovibrio & 1.30 & 4.20 & 1.60 & 2.30 \\
Dokdonella & 3.90 & 0.56 & 0.47 & 2.90 \\
\hline
\end{tabular}




\section{References}

(1) Guo, W.; Chao, S.; Chen, Q. Improved Power Generation Using Nitrogen-Doped 3D Graphite Foam Anodes in Microbial Fuel Cells. Bioproc. Biosyst. Eng. 2020, 43, 143-151. 